\title{
Lip and Oral Cavity Cancer pT1 TNM Finding v6 and $v 7$
}

National Cancer Institute

\section{Source}

National Cancer Institute. Lip and Oral Cavity Cancer pT 1 TNM Finding v6 and v7. NCI

Thesaurus. Code C64411.

Lip and oral cavity cancer with tumor size 2 centimeters or less in greatest dimension.

(from AJCC 6th and 7th Eds.) 